\title{
Study of the fracture resistance of zirconia on posterior fixed partial dentures based on inter-abutment distance
}

\author{
Gi-Beom Park', Soo-Yeon Shin ${ }^{2 *}$ \\ 'Department of Oral Health, Graduate School of Health \& Welfare, Dankook University, Cheonan, Republic of Korea \\ 'Department of Prosthodontics, College of Dentistry, Dankook University, Cheonan, Republic of Korea
}

Purpose: Zirconia fixed partial dentures with mandibular $2^{\text {nd }}$ premolar and $2^{\text {nd }}$ molar as abutments are fabricated and then the effects of inter-abutment distance on fracture resistance of zirconia fixed partial dentures is studied. Materials and Methods: The materials used in this study are Cameleon S zirconia block and S2 zirconia block, which are divided into CS Group and S2 Group applying different inter-abutment distance for each material, and the sintered zirconia fixed partial denture was luted to the epoxy resin die using a temporary luting cement, and then the fracture resistance was measured by placing a 6 mm diameter hardened steel ball on the occlusal surfaces of the pontics and applying pressure at a cross head speed of $1.0 \mathrm{~mm} / \mathrm{min}$ on a universal testing machine with a load cell of $5.0 \mathrm{kN}$. Results: The fracture resistance of zirconia fixed partial dentures is not significantly affected by inter-abutment distance The fracture resistance of zirconia fixed partial dentures in CS Group was significantly higher in 15 mm of inter-abutment distance than in $13 \mathrm{~mm}$ and $17 \mathrm{~mm}$ of inter-abutment distance $(P<0.05)$. The fracture resistance of zirconia fixed partial dentures in S2 Group was not significantly different between the three groups $(P>0.05)$. Conclusion: The fracture resistance of zirconia fixed partial dentures with mandibular $2^{\text {nd }}$ premolar and $2^{\text {nd }}$ molar as abutments does not significantly affected by the inter-abutment distance. (J Dent Rehabil Appl Sci 2020;36(2):61-9)

Key words: zirconia; fixed partial denture; fracture resistance; inter-abutment distance

\begin{abstract}
서론
치과용 수복재료는 선천적 결손이나 질병으로 상실되 거나 손상된 치아 경조직을 대체하여 치아 외형과 기능 을 회복하기 위하여 사용하는 재료를 말한다. 이러한 재 료들은 저작압에 견딜 수 있는 높은 기계적 성질을 가지 면서도 심미적이어야 한다. 또한, 생체에 친화적이고 타 액 속에서 장기간 사용이 가능한 화학적 내구성을 가져 야 한다. ${ }^{1}$ 최근 심미성을 추구하는 사회적 분위기를 반영 하여 치과분야에서도 심미수복의 비중 및 빈도는 늘어나 고 있으며 따라서 하부의 금속구조물 때문에 심미성이라

*Correspondence to: Soo-Yeon Shin

Professor, Department of Prosthodontics, College of Dentistry, Dankook University, Dandae-ro 119, Dongnam-gu, Cheonan, 31116, Republic of Korea

Tel: +82-41-550-0256, Fax: +82-41-550-1975, E-mail: syshin@dankook.ac.kr

Received: February 15, 2020/Last Revision: April 14, 2020/Accepted: May 11, 2020
\end{abstract}

는 측면에서 분명한 한계를 갖는 금속도재관의 비중은 줄고 전부도재관의 임상적용이 증가하는 추세이다. 하 지만 전부도재관은 생체친화성, 심미성, 화학적 저항성, 치태침착 감소 등의 장점을 갖고 있으나 ${ }^{2}$ 상대적으로 취 성이 높고 인장강도가 낮아 ${ }^{3}$ 특히 구치부 고정성 국소의 치의 적용에는 제한적이었다. ${ }^{4}$ 그래서 전부도재관의 단 점인 취성과 낮은 인장강도를 개선하기 위해 알루미나 (aluminum oxide), 백류석(leucite), 리튬 다이실리케이트 (lithium disilicate), 지르코니아(zirconium oxide) 등을 이용한 강화형 도재가 개발되어 전부도재 수복물이 구치 부 단일수복 뿐만 아니라 고정성 국소의치에까지 적용범

CopyrightC 2020 The Korean Academy of Stomatognathic Function and Occlusion. (c) It is identical to Creative Commons Non-Commercial License. 
위를 넓히고 있다. 구치부에서 전부도재관 수복은 교합 력과 관련하여 큰 강도를 요구한다. 따라서 강화형 도재 중 가장 높은 강도를 갖는 지르코니아가 주목받고 있으 며, ${ }^{5}$ 지르코니아는 구치부 세라믹 치관, ${ }^{6}$ 세라믹 포스트, ${ }^{7}$ 전치부 및 구치부 세라믹 브릿지, ${ }^{8}$ 임플란트 매식체, 교 정용 브라켓 ${ }^{9}$ 등에 사용되고 있다. 특히 치과영역에서는 CAD (computer-aided design) - CAM (computer-aided manufacturing) 기술을 이용한 보철물 제작 시 정밀도와 편리성이 향상되면서 강도와 파괴 인성이 높고 생체적합 성이 우수한 지르코니아를 이용한 수복물 제작이 증가하 고 있는 추세이다. ${ }^{10}$

지르코니아를 이용한 보철물을 설계하고 제작할 때 연 결부의 면적을 증가시키는 것은 무엇보다 중요하지만 수 직적인 치아크기의 제한으로 연결부를 위한 공간은 제약 되며 심미적인 이유, 위생관리의 용이성을 고려해야 하기 때문에 연결부는 좁아지는 형태를 보이므로 강도만을 고 려한 연결부 설계에는 한계가 있다. ${ }^{11}$ 고정성 국소의치는 대부분의 응력이 연결부에 집중되며 ${ }^{2}$ 연결부에 집중된 응력은 보철물의 파절의 원인이 되고, 균열은 연결부에서 기시되는 양상을 보이므로 보철물의 파절저항성에는 이 부위 코핑의 형태 및 면적이 중요한 역할을 한다. ${ }^{13}$ 또한 여러 저자들은 수복물의 성공을 위한 영향 인자로 연결 부의 반경을 언급하였다. ${ }^{14}$

환자에게 수복된 지르코니아 고정성 국소의치의 실패 의 양상은 파절, 접착실패, 이차우식, 지각과민 등으로 나 타나며 가공치의 개수가 많을수록, 그리고 전치부보다는 구치부로 갈수록 실패의 위험요소가 높아진다. ${ }^{15}$ 하지만 비교적 무치악 부위의 길이가 짧은 구강 내 구치부에 수 복된 3 본 지르코니아 고정성 국소의치는 3 년간의 추적관 찰 기간 동안 충분히 안정적으로 사용할 수 있다고 보고 된 바가 있다. ${ }^{16}$ 이에, 본 연구의 목적은 지르코니아 구치 부 고정성 국소의치의 지대치 간 거리에 따른 파절저항성 의 변화여부를 확인하여 임상적으로 적용 가능한 지대치 간 거리를 알아보기 위함이다.

\section{연구 재료 및 방법}

\section{지르코니아 고정성 국소의치의 제작}

본 연구에서는 지르코니아 고정성 국소의치를 제작하 기 위하여 지대치 금속 모형을 제작하였다. 소구치 지대 치는 지름 $7.0 \mathrm{~mm}$, 높이 $10 \mathrm{~mm}$ 와 대구치 지대치는 지름
$11 \mathrm{~mm}$, 높이 $10 \mathrm{~mm}$ 의 sus304 원기둥을 이용하여 두 지 대치 사이의 간격을 유동적으로 제작하였다. 블록 가공 은 MCT Machining center (50series, Hwacheon, Seoul, Korea), 원형가공은 CNC선반 (50series, Hwacheon)으 로 하였으며 연삭가공으로 후공정을 하였다. 이후, 블 록의 표면을 래핑하여 레이저 스캔을 위한 최종 금속 모 형을 얻었다. 실리콘 복재제를 사용하여 이 금속 모형 에 대한 몰드를 만들고 에폭시 레진 모형재(PolyUrock, Cendres+Métaux SA, Biel, Switzerland)를 사용하여 파 절 시험용 모형을 제작하였다. 이 모형의 지대치 크기 및 지대치 간 거리에 대한 모식도는 Fig. 1 에 나타내었다. 재 료의 종류 및 실험군을 Table 1로 정리하였다.

지르코니아 고정성 국소의치는 치과용 지르코니아 CAD-CAM 시스템인 3Shape dental system (Dentmill, Neo-biotech, Seoul, Korea)을 이용하여 제작하였다. 이 시스템은 레이저 모형 스캐너 및 설계 시스템(CAD)인 TRIOS3 Intraoral scanner, 세라믹 CAM 가공인 CAMeleon CS 및 지르코니아 소결로인 ET-Therm로 구성되 어있다.

모든 과정은 제조사의 지시대로 이루어졌다. 이 때 시 멘트의 두께는 $0.03 \mathrm{~mm}$ 로 설정되었으며, 지르코니아 코 핑의 두께는 소구치 $0.74 \mathrm{~mm}$, 대구치 $0.75 \mathrm{~mm}$ 로 지정 하였다. 이후 지대치 간 거리를 실험 조건에 따라 각각 $13,15,17 \mathrm{~mm}$ 로 설정하였다. Cameleon S block (Neobiotech)과 Luxen S2 block (Dentalmax, Seoul, Korea) 을 이용하여 $1350^{\circ} \mathrm{C}$ 에서 약 12 시간 동안 소결하여 지르 코니아 고정성 국소의치 코핑 시편을 제작하였다.

본 연구에서는 지대치 간 거리에 따른 지르코니아 고정 성 국소의치의 파절저항성을 비교하기 위하여 제조사에 서 제시한 굽힘 강도 값이 유사하고, 국내에서 임상적으 로 많이 사용되는 Cameleon S block과 Luxen S2 block 을 사용하였다. 먼저 가공치는 프로그램에서 자동으로 설정되는 위치에 설계 하였으며 지대치 간 거리를 $13 \mathrm{~mm}$ 로 하여 고정성 국소의치 코핑을 제작하였다(1군). 또한 다른 조건은 1 군과 동일하고 지대치 간 거리를 $15 \mathrm{~mm}$ 로 하여 고정성 국소의치 코핑을 제작하였다(2군). 마지 막으로 다른 조건은 1 군, 2 군과 동일하고 지대치 간 거리 를 $17 \mathrm{~mm}$ 로 하여 고정성 국소의치 코핑을 제작하였다(3 군). 지대치 간 거리에 따른 디자인은 Fig. 2에 나타내었 다. 각 제조회사별 군에 6 개씩 18 개의 지르코니아 고정성 국소의치 시편을 절삭 가공하여 총 36 개의 지르코니아 고정성 국소의치 시편을 준비하였으며, 각 시편의 사진은 

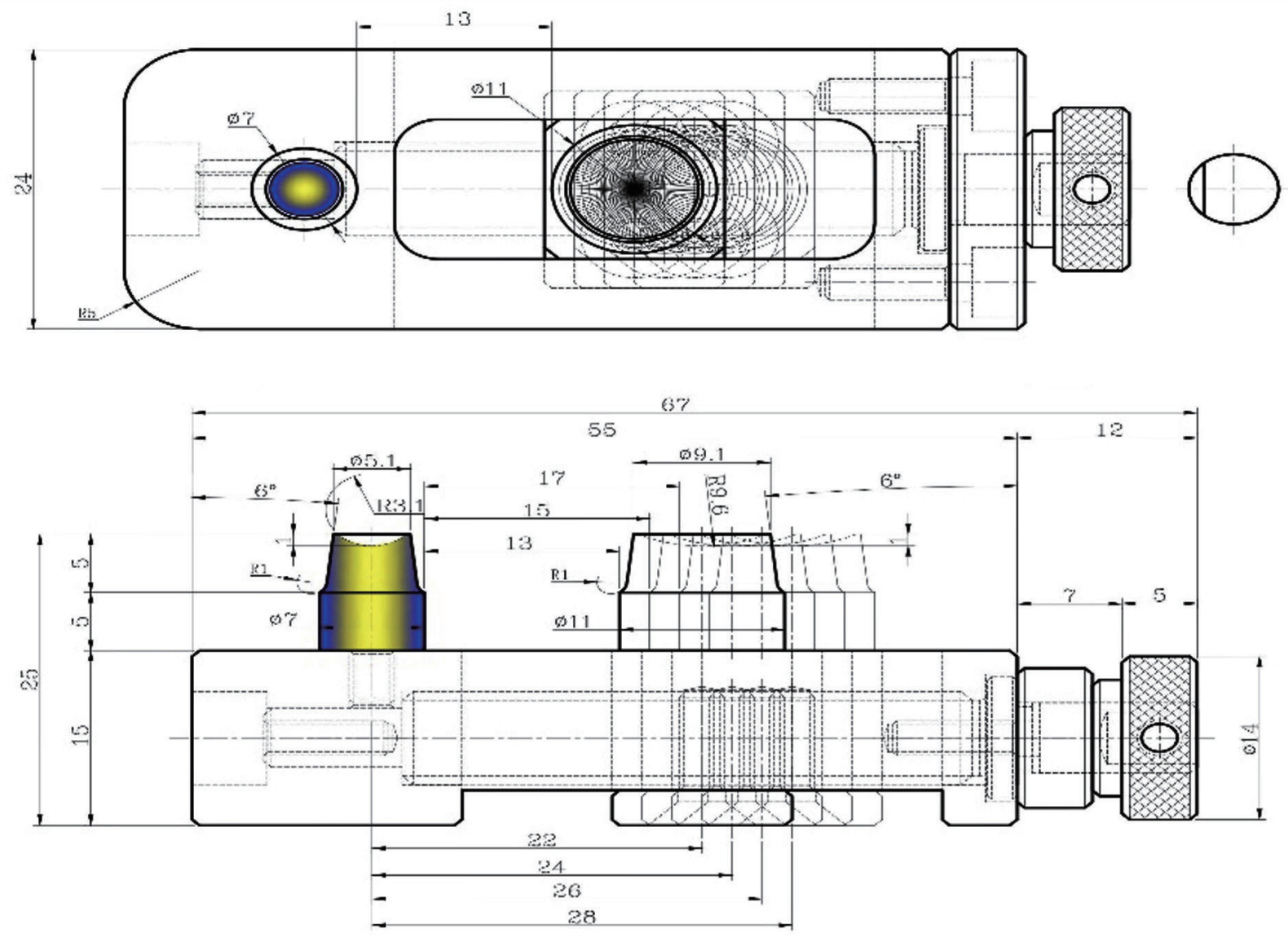

Fig. 1. Master steel die design.

Table. 1. Zirconia experimental group

\begin{tabular}{cccc}
\hline & $\begin{array}{c}13 \mathrm{~mm} \\
(\text { Group 1) }\end{array}$ & $\begin{array}{ccc}15 \mathrm{~mm} \\
(\text { Group 2) }\end{array}$ & $\begin{array}{c}17 \mathrm{~mm} \\
(\text { Group 3) }\end{array}$ \\
\hline CS & 6 piece & 6 piece & 6 piece \\
S2 & 6 piece & 6 piece & 6 piece \\
\hline
\end{tabular}

CS, Cameleon S block; S2, S2 block.

Fig. 3 에 나타내었다. 두 제조회사를 구별하기 위해 각 군 앞에 Neo-biotech의 Cameleon S block은 CS, Luxen의 $\mathrm{S} 2$ block은 S2로 표기하였다.
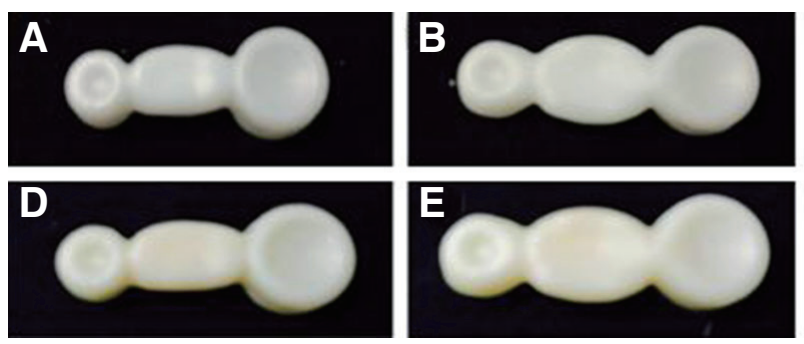

A

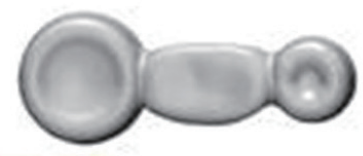

B

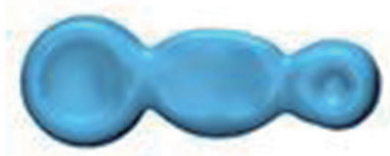

C

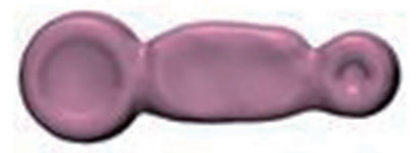

Fig. 2. Design of zirconia fixed partial denture. Differency of color according to inter-abutment distance. (A) White $13 \mathrm{~mm}$, (B) Blue $15 \mathrm{~mm}$, (C) Purple $17 \mathrm{~mm}$.
Fig. 3. Specimens of zirconia fixed partial denture. (A) CS $13 \mathrm{~mm}$, (B) CS 15 mm, (C) CS $17 \mathrm{~mm}$, (D) S2 13 mm, (E) S2 15 mm, (F) S2 17 mm. 


\section{지르코니아 고정성 국소의치의 파절저항성 측정}

소결된 지르코니아 고정성 국소의치는 임시접착시멘 트(CharmTemp EU, Dentkist, Gunpo, Korea)를 이용 하여 각각 에폭시 레진 다이에 합착하였다. 시편들의 파 절강도는 가공치의 교합면에 직경 $6 \mathrm{~mm}$ 의 강철구(hardened steel ball)를 위치시키고 로드셀 $5.0 \mathrm{kN}$ 의 재료시험 기(Instron 5966, Instron, Norwood, USA)에서 크로스 헤드 속도 $1.0 \mathrm{~mm} / \mathrm{min}$ 로 압력을 가하여 최대 파절하중 (N)을 구하였다(Fig. 4). 이 때 강철구와 지르코니아 교합 면 사이에 $0.02 \mathrm{~mm}$ 두께의 알루미늄 호일을 개재시켜 접 촉파절을 방지하였다.

\section{통계분석}

통계처리는 IBM SPSS Statistics 23을 이용하여 분석 하였다. 데이터를 일원배치분산분석(One-way ANOVA test)을 실시하여 각 군의 유의한 차이를 파악한 후 유의 한 차이가 있는 경우 군 간의 비교를 위해 사후검정은 Scheffe's test를 실시하였다. 유의수준은 $P=0.05$ 로 하 였다.

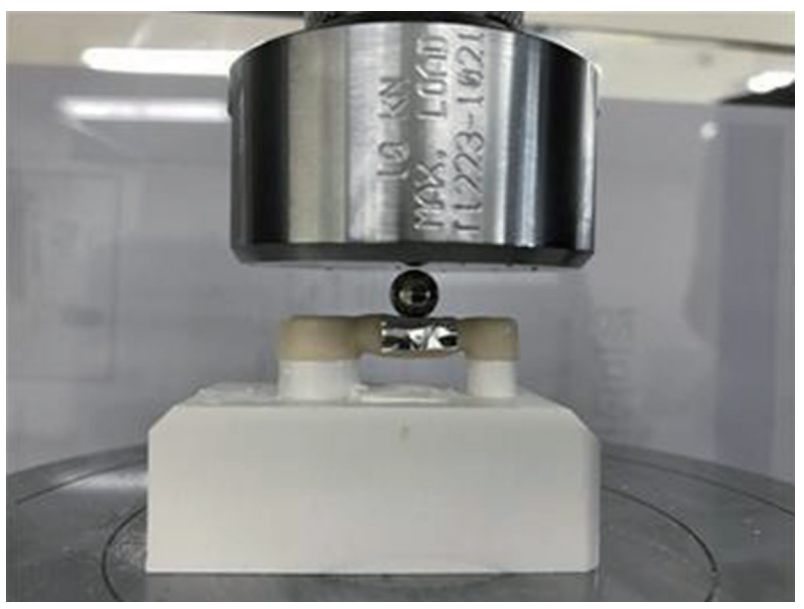

Fig. 4. Photograph of fracture test of S2 zirconia fixed partial dentures.

\section{결과}

각 군 내 평균 파절하중은 Table 2로 정리하였다. CS 군 내에서 최소 파절하중은 지대치 간 거리가 $13 \mathrm{~mm}$ 였 을 때 $1200 \mathrm{~N}$ 이었으며, 최대 파절하중은 지대치 간 거리 가 $15 \mathrm{~mm}$ 였을 때 $2492 \mathrm{~N}$ 으로 나타났다. CS군 내 1군 의 평균 파절하중은 $1605.39 \mathrm{~N}, 2$ 군의 평균 파절하중은 $2243.35 \mathrm{~N}, 3$ 군의 평균 파절하중은 $1835.85 \mathrm{~N}$ 이었으며 이 중, 2 군에서 가장 큰 평균 파절하중을 나타내었다. CS 군 내에서 지대치 간 거리에 따른 통계적 유의한 차이가 1 군과 2 군, 2 군과 3 군 간에서 나타났다. S2군에서 최소 파절하중은 지대치 간 거리가 $13 \mathrm{~mm}$ 일 때 $1197 \mathrm{~N}$, 최대 파절하중은 지대치 간 거리가 $17 \mathrm{~mm}$ 일 때 $2638 \mathrm{~N}$ 으로 나타났다. S2군 내 1군의 평균 파절하중은 $1766.01 \mathrm{~N}, 2$ 군의 평균 파절하중은 $1999.28 \mathrm{~N}, 3$ 군의 평균 파절하중 은 $2158.79 \mathrm{~N}$ 이었다. 평균 파절하중은 3 군에서 가장 높 은 값을 보였으나, 지대치 간 거리에 따른 통계적 유의한 차이는 없었다.

\section{고찰}

높은 강도와 심미성을 가진 수복물에 대한 치과계의 관심은 과거부터 있었다. 지르코니아는 높은 강도와 심 미성뿐만 아니라, 생체적합성, 내마모성, 균열성장억제, 구조적 및 화학적 안정성을 지니고 있는 재료이다. ${ }^{17,18}$ 높 은 강도를 가진 지르코니아의 가공을 위해서는 반드시 $\mathrm{CAD}-\mathrm{CAM}$ 을 이용한 가공절삭이 필요하다. CAD-CAM 시스템을 이용하여 보철물을 제작하는 방법은 일반적인 방법에 비해 많은 장점이 있으며 그 중 보철물 제작의 동 일화 및 대량생산이 가능하다는 점이다. 지르코니아 코 핑의 두께 및 연결부의 면적과 같은 특정부위의 설계를 정량화하기 위해 반드시 컴퓨터를 이용하여 작업을 해야 한다. ${ }^{19}$ 그러나 CAD-CAM 시스템 도입 초반에는 지르코 니아 코핑의 적합성 및 몇 가지 임상적 문제가 발생했지 만 기술의 발전으로 인해 여러 문제 중 일부가 해결되었

Table. 2. Scheffe's correlation coefficient accoding to inter-abutment of zirconia fixed partial denture

\begin{tabular}{cccc}
\hline & $13 \mathrm{~mm}$ & $15 \mathrm{~mm}$ & $17 \mathrm{~mm}$ \\
\hline CS & $1,605.39(322.11)^{\mathrm{a}}$ & $2,243.35(221.93)^{\mathrm{b}}$ & $1,835.85(231.95)^{\mathrm{ab}}$ \\
S2 & $1,766.01(388.38)^{\mathrm{a}}$ & $1,999.28(226.03)^{\mathrm{a}}$ & $2158.79(345.01)^{\mathrm{a}}$ \\
\hline
\end{tabular}

CS, Cameleon S block; S2, S2 block.

The same superscripts denotes groups that were not significantly different from each other $(P>0.05)$. 
으며 임상적으로 수용 가능한 적합도를 갖게 되었다. ${ }^{20,21}$

재료적 특성으로 볼 때, 취성 물질인 지르코니아는 충 분한 두께가 제공되지 않으면 파절될 수 있으며, ${ }^{22}$ 알루미 나 또는 리튬 다이실리케이트와 같은 재료보다는 취성강 도가 높고 넓은 범위의 기계적 저항성이 보고되어 재료의 설계가 파절저항성에 영향을 미칠 수 있음을 나타낸다. ${ }^{23}$ 비교적 짧은 기간 내에 지르코니아 코핑의 파절이 나타 난다는 몇 가지 임상적 보고가 있다. ${ }^{24,25}$ 이러한 임상적 보고서는 적절하지 않은 연결부위의 면적 및 축벽의 감소 와 같은 잘못된 설계가 파절의 주요원인임을 제시하였는 데, Takuma 등은 연결부위의 두 가지 $\left(9 \mathrm{~mm}^{2}, 7 \mathrm{~mm}^{2}\right)$ 단 면적과 세 가지(1:1, 3:4, 2:3) 단면적 형태(height : width) 에 따라 제 1 소구치와 제 2 대구치를 지대치로 하는 4 본 지 르코니아 고정성 국소의치의 파절저항성을 실험한 결과 단면적 그리고 단면적의 형태에 따라 파절저항성에 큰 차이를 나타내었으며 $(P<0.01)$ 단면적의 형태가 근/원 심으로 넓은 형태보다 수직으로 넓은 형태가 파절저항성 이 크다고 보고한 바가 있다. 그러나 단면적과 단면적의 형태에 관하여 통계적 유의한 차이를 나타내지 않았으며 단면적과 파절저항성은 비례관계를 나타내었다. ${ }^{26} \mathrm{SeO}$ 등 은 제 2 소구치와 제 1 대구치를 지대치로 하는 지르코니아 고정성 국소의치의 연결부위의 설측 보강 설계가 파절저 항성에 미치는 영향을 실험한 결과 설측에 보강하지 않 은 대조군과 설측에 $1 \mathrm{~mm}$ 보강한 실험군 그리고 $2 \mathrm{~mm}$ 보강한 실험군에서는 통계적으로 유의한 차이가 나타났 으며 $3 \mathrm{~mm}$ 보강한 실험군은 유의한 차이를 나타내지 않 았다고 보고되었다. ${ }^{27}$ 또한 Ogino 등은 네 가지 $\left(9 \mathrm{~mm}^{2}\right.$, $7 \mathrm{~mm}^{2}, 5 \mathrm{~mm}^{2}, 3 \mathrm{~mm}^{2}$ ) 단면적과 세 가지 단면적 형태에 따라 우측 중절치와 좌측 측절치를 지대치로 하는 지르 코니아 고정성 국소의치 보철물을 치주인대와 유사한 작 용을 하는 실리콘 홀더에 반구형 정점을 가진 금속 다이 에 시편을 합착하여 파절 실험을 한 결과, 단면적이 가장 큰 $9 \mathrm{~mm}^{2}$ 보철물이 가장 높은 파절 하중 값을 나타냈으 며, 단면적과 단면적의 형태가 파절저항성에 매우 중요한 영향을 미친다는 것을 보고하였다. ${ }^{28}$

고정성 국소의치의 연결부위 설계에 따라 3점 굴곡강 도에 저항하는 하중 값을 연구한 결과에 따르면, Hamza 등은 고정성 국소의치의 연결부위 설계 시 날카로운 연 결부위 설계보다 둥근 연결부위 설계가 교합력을 더 견 딜 수 있다고 보고하였다. ${ }^{29}$ 또한, 고정성 국소의치 보철 물 제작 시 제작하는 사람에 따라 가공치의 위치가 달라 질 것으로 사료된다. 이에 관한 연구로 Bok 등은 가공치
의 위치에 따른 구치부 고정성 국소의치의 파절저항성을 연구한 결과 제한된 가공치 범위 내에서 가공치가 근심 에 위치할 때 원심에 위치한 것보다 파절저항성이 낮게 나타났다고 보고하였으며 ${ }^{30}$ 가공치의 위치를 프로그램의 설정에 따라 위치시킨 후 파절저항성을 실험한 결과 값을 본 연구와 비교하였을 때 전자의 Uncolored 지르코니아 의 파절하중 값은 $1270 \mathrm{~N}$, Colored 지르코니아의 파절하 중 값은 $1311 \mathrm{~N}$ 이며 본 연구에서는 CS군 파절하중 값이 $1894 \mathrm{~N}, \mathrm{~S} 2$ 군 파절하중 값은 1974 N으로 본 연구에서의 파절하중 값이 훨씬 높게 나왔다. 그 이유는 지르코니아 고정성 국소의치의 연결부위 면적에서의 차이 때문이라 고 사료된다. 전자는 연결부위의 면적을 $9 \mathrm{~mm}^{2}$ 로 설계하 였고 본 연구에서는 임상적으로 설계하여 제 2 소구치 쪽 은 $16 \mathrm{~mm}^{2}$, 제2대구치 쪽은 $17 \mathrm{~mm}^{2}$ 로 하였기 때문이라 고 사료된다. 이와 같은 연구들은 모두 지르코니아 코핑 의 설계 및 가공치 위치에 따른 파절저항성 및 굴곡강도 를 연구하여 보고된 것들이다.

한편, 앞서 보고된 연구들과는 달리 지르코니아에 여 러 가지 표면처리 및 강도를 높이는 물질을 침투시켜 굽 힘강도와 굴곡강도의 증가시킨 연구들이 보고되었는데, $\mathrm{Seo}$ 등은 에이징이 샌드블라스팅 된 지르코니아 세라믹 의 굽힘 강도에 미치는 연구를 실험한 결과 에이징 시간 에 따른 지르코니아의 굽힘 강도는 통계적으로 유의미한 차이를 보이지 않았으나, 데이터의 경향성을 반영하는 회귀선에서는 에이징 시간과 굽힘 강도의 반비례 관계를 나타내었는데 그 원인이 샌드블라스팅으로 인해 생성된 미세 균열이 지르코니아 강도에 영향을 주는 것으로 사 료된다고 보고하였다. ${ }^{31} \mathrm{Jang}$ 은 지르코니아와 글라스 층 을 제거하지 않은 글라스 용융 침투 지르코니아 및 글라 스 층을 제거한 글라스 용융 침투 지르코니아를 비교하 여 산화철이 함유된 글라스 용융 침투된 지르코니아의 강도에 관한 연구를 한 결과 글라스 층을 제거하지 않은 글라스 용융 침투한 지르코니아와 글라스 층을 제거한 글라스 용융 침투한 지르코니아 모두에서 대조군인 지 르코니아에 비해 유의하게 높은 굴곡강도를 나타냈다고 보고하였다. ${ }^{32}$ 앞서 보고된 연구들은 지르코니아의 강도 를 높이는 것에 중점을 두고 실험하여 임상에 큰 도움이 되고 있다고 사료된다. 그러나 현재까지 보고된 지르코 니아 고정성 국소의치의 파절저항성 실험에 대한 연구에 대해 지대치 간 거리를 변수로 둔 연구는 많지 않아 이 연 구를 하게 되었다. 또한, 금관과는 달리 지르코니아는 완 전소결을 거쳐야 구강 내 교합압에 견딜 수 있는 강도를 
갖게 되는데, 지르코니아의 소결 조건에 따른 굴곡강도 에 관한 연구를 볼 때, $\mathrm{Kim}$ 등은 지르코니아의 소결 조건 을 시간 $(1 \mathrm{~h}, 2 \mathrm{~h})$ 과 온도 $\left(1350^{\circ} \mathrm{C}, 1500^{\circ} \mathrm{C}, 1650^{\circ} \mathrm{C}\right)$ 에 따 라 실험군을 나누어 지르코니아의 소결 조건이 굴곡강도 에 미치는 영향을 연구한 결과 이축굴곡강도 실험에서 2 시간 소결한 조건이 1 시간 소결한 조건보다 높은 강도를 보였으며, 소결 온도가 높을수록 강도가 증가한다고 보 고하였다. ${ }^{33}$ 그러므로 소결 시간 및 소결 온도를 높여 지 르코니아 보철물의 강도를 높이는 것이 옳은 것으로 사 료되지만 현재 많은 치과 의료 장비 회사들이 각 장비에 맞는 권장 조건들을 제시하고 있으며 제시한 조건을 벗 어나는 프로그램을 사용할 경우 장비에 이상이 생길 수 있는 위험이 있으므로 반드시 기공실 및 기공소에 있는 장비의 권장사항과 비교해 소결 조건을 적용해야 하며, 본 연구는 제조사에서 권장하는 $1350^{\circ} \mathrm{C}$ 에서 약 12 시간 을 소결하여 파절저항성 실험을 하였다. 그러나 앞에 보 고된 연구와 달리 $1650^{\circ} \mathrm{C}$ 보다 낮은 온도인 $1350^{\circ} \mathrm{C}$ 에서 소결하였지만 CS군의 평균 파절하중은 $1894 \mathrm{~N}$ 과 S2군의 평균 파절하중이 $1974 \mathrm{~N}$ 으로 구강 내 구치부 교합력에 충분히 견딜 수 있을 정도의 파절하중 값을 갖고 있다고 사료된다.

최근 심미수복의 수요 증가로 과거에 사용하던 금관 및 금속도재관보다 백색 지르코니아 블록을 밀링하여 만 든 보철물의 사용이 증가하고 있다. 이에 따라 점차 기 술의 발전을 통해 백색 지르코니아 블록에 색상을 띄는 물질을 첨가한 Multi-layered 지르코니아 블록을 생산하 여 보다 나은 색조를 띄는 보철물에 더욱 관심을 갖게 되 었다. 하지만 지르코니아 블록의 도입 초반에 관한 연구 결과에 따르면, Park 등은 다층의 색상이 첨가된 지르코 니아 크라운의 파절저항성을 비교하여 심미적이고 충분 한 강도를 가지는지에 대한 연구를 한 결과 다층의 색상 이 첨가된 지르코니아 블록이 기존의 백색 블록에 비해 파절저항성은 낮았으나 임상적으로 구치부에서 발생하 는 교합력은 충분히 견딜 수 있는 파절저항성을 보였으 며, 파절강도가 가장 높게 나타난 실험군의 원인은 다른 실험군에 비해 미세결정입자 크기가 $0.5 \mu \mathrm{m}$ 이하를 갖고 있기 때문이라고 보고하였다. ${ }^{34}$ 그러나, 본 연구에서는 백 색 블록으로 밀링한 CS군과 Multi-layered 지르코니아 블 록으로 밀링한 S2군 간에 평균 강도를 비교하였을 때 CS 군의 평균 파절하중은 $1894 \mathrm{~N}, \mathrm{~S} 2$ 군의 평균 파절하중은 1974 N으로 백색 블록에 비해 Multi-layered 지르코니아 블록의 파절하중이 더 높아 상반된 결과를 나타냈다. 앞
선 연구에 상반된 결과의 이유를 고려하였을 때, Multilayered 지르코니아 블록의 도입 후 보철물의 색조는 훨 씬 좋았으나 파절저항성이 백색 블록에 비해 약하다는 임상적 결과들을 통해 구강 내에서 견딜 수 있는 파절저 항성 문제들을 보완하여 Multi-layered 지르코니아 블록 의 파절저항성이 백색 블록에 비해 높게 나온 것이라 사 료된다.

지르코니아 고정성 국소의치의 파절저항성에 관한 연 구에서 실험하는 방법에 있어 기존의 연구들과 몇 가지 차이점들을 발견할 수 있었다. 첫째로, 시편의 형태에 차 이가 있었는데 바, 코핑, 크라운 등이 있었다. 둘째로, 코 핑이나 크라운 형태의 시편들을 파절저항성 실험 시 에 폭시 레진 다이 또는 금속 다이에 합착하는 차이가 있었 다. 본 연구에서 에폭시 레진 다이에 지르코니아 고정성 국소의치 시편을 합착한 이유는 치아와 유사한 탄성계수 를 갖고 있기 때문이다. 물론 실험하는 방법은 연구마다 조금씩 다르지만 결론적으로 시사하는 바는 동일하였다. 그러나 치과보철물의 재료적 특성을 연구하는 것 또한 중요하지만 결론적으로 치과보철물은 구강 내에 합착되 어 여러 요인들에 의해 파절되고 문제가 발생한다고 사 료된다. 그러므로 실제 임상에서 사용하고 설계하는 보 철물들의 연구들이 보다 더 많은 연구가 필요하다고 사 료된다. 본 연구에서는 구강 내 지대치 상황이 여러 요인 들로 인해 환자에 따라 지대치 간 거리가 다를 것을 고려 하여 실험하였다. 그러나 지르코니아 고정성 국소의치의 지대치 간 거리에 따른 파절저항성에 통계적으로 유의 한 차이를 나타낸 것은 $\mathrm{CS}$ 군의 $13 \mathrm{~mm}$ 와 $15 \mathrm{~mm}$ 그리고 $15 \mathrm{~mm}$ 와 $17 \mathrm{~mm}$ 이지만, S2군에서는 통계적으로 유의한 차이를 나타내지 않았다. 그러므로 제한적인 이 연구에 서 CS군에서는 지대치 간 거리가 통계적으로 유의한 영 향을 보였지만, S2군은 차이가 없었으므로, 지르코니아 의 종류에 따라 지대치 간 거리가 파절저항성에 영향을 미칠 수 있다는 결론을 얻었다. 다만, 가공치는 프로그램 에서 자동으로 설정되는 위치에 설계되었는데, 이로 인해 가공치의 협설 폭경에 있어 실험군 간에 다소 차이가 발 생하였으며, 특히 CS군에서 지대치 간 거리가 $15 \mathrm{~mm}$ 인 경우에 유의성 있게 높은 파절저항값을 나타내게 된 것 으로 보인다. 본 연구는 각 실험군 내의 가공치와 지대치 사이의 연결부위 폭이나 가공치의 형태가 다르게 제작되 어 변수가 다양하게 나타나기에, 실험 설계에 있어 한계 가 존재하며, 이에 따라 가공치 설계에 대한 실험방법의 표준화가 반영된 추가 연구가 필요할 것으로 사료된다. 
본 연구에서는 하악 제 1 대구치만을 가공치로 하는 제 한적인 실험 설계로, 가공치의 개수가 많거나 구강 내 위 치를 다르게 하였을 때의 지르코니아 고정성 국소의치의 파절저항성을 측정하는 것에는 더 많은 연구가 필요할 것이라 사료된다. 또한 실험 시 하중은 가공치의 교합면 에만 국한되어 사용되었기에 하중을 지대치의 교합면에 가했을 때의 파절저항성을 측정하기에는 실험의 설계의 보완이 필요하다고 사료된다. 비록 본 연구는 CS군에서 의 결과 값 중 지대치 간 거리가 $15 \mathrm{~mm}$ 인 지르코니아 고 정성 국소의치 코핑의 파절저항성이 가장 큰 결과 값을 보였으나, S2군에서는 유의한 차이를 나타내지 않은 것 을 볼 때, 지르코니아 고정성 국소의치 시편 수가 많지 않 고 구강 내 환경을 유사하게 재현해 내는 것에 대한 제한 이 있었기에 제조회사 간의 상이한 차이를 나타내는 것 으로 보아 추가적인 연구 분석이 필요할 것으로 사료된 다. 또한, 가공치 설계 역시 임상적인 상황을 충분히 반영 하여 적용되어야 적절한 파절강도를 얻을 수 있을 것이 다. 지대치 간 거리 요인을 두고 실험한 결과 구치부 고정 성 국소의치를 제작할 경우 지대치 간 거리를 고려하는 것은 좀 더 많은 연구가 필요할 것으로 사료되며 개인에 따라 Spee 만곡 역시 차이를 보이므로 그 재현성에도 실 험 시 염두에 두어야 할 것이라 사료된다. 따라서 구치부 고정성 국소의치의 파절저항성에 영향을 미칠 수 있으므 로 좀더 다양한 변수를 둔 연구가 필요하다 사료된다.

\section{결론}

본 연구에서는 하악 좌측 제 1 대구치가 결손되어 제 2 소 구치와 제 2 대구치를 지대치로 하는 지르코니아 고정성 국소의치를 제작하고 지대치 간 거리가 파절저항성에 미 치는 영향을 비교하였다. 본 연구의 재료 및 방법의 범위 내에서 결과로부터 다음과 같은 결론을 얻었다.

지르코니아 고정성 국소의치 CS군에서 1 군과 2 군, 2 군과 3군에서 통계적 유의한 차이를 보였으며, 지대치 간 거리가 $15 \mathrm{~mm}$ 인 2군이 가장 큰 파절저항값을 보였다(2 군 $>1$ 군 $=3$ 군).

지르코니아 고정성 국소의치 S2군에서 지대치 간 거리 에 따른 파절저항성은 모든 군에서 통계적 유의한 차이 를 보이지 않았다 $(1$ 군 $=2$ 군 $=3$ 군 $)$.

\section{ORCID}

Gi-Beom Park https://orcid.org/0000-0001-5550-0211

Soo-Yeon Shin https://orcid.org/0000-0001-6160-7277

\section{References}

1. Lee HH. Recent Dental Ceramics: Processing and Strengthening. J Korean Res Soc Dent Mater 2000;27:111.

2. Ardlin BI. Transformation-toughened zirconia for dental inlays, crowns and bridges: chemical stability and effect of low-temperature aging on flexural strength and surface structure. Dent Mater 2002;18: 590-5.

3. Sobrinho LC, Cattell MJ, Glover RH, Knowles JC. Investigation of the dry and wet fatigue properties of three all-ceramic crown systems. Int J Prosthodont 1998;11:255-62.

4. Campbell SD, Sozio RB. Evaluation of the fit and strength of an all-ceramic fixed partial denture. J Prosthet Dent 1988;59:301-6.

5. Tinschert J, Natt G, Mautsch W, Augthun M, Spiekermann H. Fracture resistance of lithium disilicate-, alumina-, and zirconia-based three-unit fixed partial dentures: a laboratory study. Int J Prosthodont 2001;14:231-8.

6. Kohorst P, Herzog TJ, Borchers L, Stiesch-Scholz M. Load-bearing capacity of all-ceramic posterior four-unit fixed partial dentures with different zirconia frameworks. Eur J Oral Sci 2007;115:161-6.

7. Meyenberg KH, Lüthy H, Schärer P. Zirconia posts: a new all-ceramic concept for nonvital abutment teeth. J Esthet Dent 1995;7:73-80.

8. Wagner WC, Chu TM. Biaxial flexural strength and indentation fracture toughness of three new dental core ceramics. J Prosthet Dent 1996;76:140-4.

9. Keith O, Kusy RP, Whitley JQ. Zirconia brackets: an evaluation of morphology and coefficients of friction. Am J Orthod Dentofacial Orthop 1994;106:605-14.

10. Tinschert J, Natt G, Mautsch W, Spiekermann $\mathrm{H}$, Anusavice KJ. Marginal fit of alumina- and zirconia-based fixed partial dentures produced by a CAD/CAM system. Oper Dent 2001;26:367-74.

11. Oh W, Götzen N, Anusavice KJ. Influence of con- 
nector design on fracture probability of ceramic fixed-partial dentures. J Dent Res 2002;81:623-7.

12. El-Ebrashi MK, Craig RG, Peyton FA. Experimental stress analysis of dental restorations. VII. structural design and stress analysis of fixed partial dentures. J Prosthet Dent 1970;23:177-86.

13. Fischer H, Weber M, Marx R. Lifetime prediction of all-ceramic bridges by computational methods. J Dent Res 2003;82:238-42.

14. Mahmood DJ, Linderoth EH, Von Steyern PV, Wennerberg A. Fracture strength of all-ceramic (YTZP) three- and four-unit fixed dental prostheses with different connector design and production history. Swed Dent J 2013;37:179-87.

15. Schmitter M, Mussotter K, Rammelsberg P, Gabbert O, Ohlmann B. Clinical performance of longspan zirconia frameworks for fixed dental prostheses: 5-year results. J Oral Rehabil 2012;39:552-7.

16. Sailer I, Fehér A, Filser F, Lüthy H, Gauckler LJ, Schärer P, Franz Hämmerle CH. Prospective clinical study of zirconia posterior fixed partial dentures: 3-year follow-up. Quintessence Int 2006;37:685-93.

17. Guazzato M, Albakry M, Ringer SP, Swain MV. Strength, fracture toughness and microstructure of a selection of all-ceramic materials. Part II. Zirconia-based dental ceramics. Dent Mater 2004;20:44956.

18. Luthardt RG, Sandkuhl O, Herold V, Walter MH. Accuracy of mechanical digitizing with a CAD/ CAM system for fixed restorations. Int J Prosthodont 2001;14:146-51.

19. Dahlmo KI, Andersson M, Gellerstedt M, Karlsson $\mathrm{S}$. On a new method to assess the accuracy of a CAD program. Int J Prosthodont 2001;14:276-83.

20. Moldovan O, Luthardt RG, Corcodel N, Rudolph H. Three-dimensional fit of CAD/CAM-made zirconia copings. Dent Mater. 2011;27:1273-8

21. Beuer F, Naumann M, Gernet W, Sorensen JA. Precision of fit: zirconia three-unit fixed dental prostheses. Clin Oral Investig 2009;13:343-9.

22. Al-Amleh B, Lyons K, Swain M. Clinical trials in zirconia: a systematic review. J Oral Rehabil 2010;37:64152.

23. Manicone PF, Iommetti PR, Raffaelli L. An overview of zirconia ceramics: basic properties and clinical applications. J Dent 2007;35:819-26.

24. Tinschert J, Schulze KA, Natt G, Latzke P, Heussen $\mathrm{N}$, Spiekermann H. Clinical behavior of zirconiabased fixed partial dentures made of DC-Zirkon: 3-year results. Int J Prosthodont 2008;21:217-22.

25. Lohbauer U, Amberger G, Quinn GD, Scherrer SS. Fractographic analysis of a dental zirconia framework: a case study on design issues. J Mech Behav Biomed Mater 2010;3:623-9.

26. Yusuke Takuma, Syuntaro Nomoto, Toru Sato, Naoki Sugihara. Effect of Framework Design on Fracture Resistance in Zirconia 4-unit All-ceramic Fixed Partial Dentures. Bull Tokyo Dent Coll 2013;54:14956.

27. Seo JY, Park IN, Lee KW. Fracture strength between different connector designs of zirconia core for posterior fixed partial dentures manufactured with CAD/CAM system. J Korean Acad Prosthodont 2006;44:29-39.

28. Ogino Y, Nomoto S, Sato T. Effect of connector design on fracture resistance in zirconia-based fixed partial dentures for upper anterior region. Bull Tokyo Dent Coll 2016;57:65-74.

29. Hamza TA, Attia MA, El-Hossary MM, Mosleh IE, Shokry TE, Wee AG. Flexural strength of small connector designs of zirconia-based partial fixed dental prostheses. J Prosthetic Dent 2016;115:2249.

30. Bok SB. Study on the fracture resistance and reliability of zirconia posterior fixed partial denture. Ph. D. thesis, Dankook University. 2009.

31. Seo HW. The effect of aging process on the flexural strength of airborne particle abraded zirconia ceramics. Master's thesis, Seoul Nat'l Univ. 2015.

32. Jang KJ. Effect of infiltration with ferric oxide contaning glass on the color, microstructure and strength of zirconia. Master's thesis, Chonnam Nat'l Univ. 2015.

33. Kim MC. Effects of zirconia sintering condition on flexural strength and grain size. Master's thesis, Korea Univ. 2014.

34. Park JW. A Comparative Study on the fracture strength of the multi coloured monolithic zirconia restoration. Kyungpook Nat'l Univ. 2016. 


\section{지르코니아 고정성 국소의치의 지대치간 거리에 따른 파절저항성에 관한 연구}

박기범 ${ }^{1}$ 대학원생, 신수연 ${ }^{2 *}$ 교수

${ }^{1}$ 단국대학교 보건복지대학원 구강보건학과

${ }^{2}$ 단국대학교 치과대학 치과보철학교실

목적: 하악 제 2 소구치와 제 2 대구치를 지대치로 한 지르코니아 고정성 국소의치에서 지대치 간 거리가 파절저항성에 미 치는 영향을 조사하였다.

연구 재료 및 방법: Cameleon S zirconia block과 Luxen S2 zirconia block으로 각 재료별 지대치 간 거리를 달리 하여 CS 군과 S2군으로 나누어 표기하였으며, 소결된 지르코니아 고정성 국소의치를 임시접착시멘트를 이용하여 에폭시 레진 다 이에 합착하였다. 이후, 가공치 교합면에 직경 $6 \mathrm{~mm}$ 강철구를 위치시켜 로드셀 $5.0 \mathrm{kN}$ 의 universal testing machine에서 크로스 헤드 속도 $1.0 \mathrm{~mm} / \mathrm{min}$ 로 압력을 가하여 파절저항성을 측정하였다.

결과: 지르코니아 고정성 국소의치의 파절저항성은 지대치 간 거리에 큰 영향을 받지 않았다. CS군에서 지대치 간 거리 가 $15 \mathrm{~mm}$ 인 경우가 $13 \mathrm{~mm}$ 와 $17 \mathrm{~mm}$ 인 경우보다 파절저항성이 유의하게 높았다 $(P<0.05)$. S2군에서는 파절저항성이 세 군 간에 유의한 차이가 없었다 $(P>0.05)$.

결론: 하악 제 2 소구치와 제 2 대구치를 지대치로 한 지르코니아 고정성 국소의치에서 지대치 간 거리는 지르코니아의 종 류에 따라 파절저항성에 영향을 줄 수 있다.

(구강회복응용과학지 2020;36(2):61-9)

주요어: 지르코니아; 고정성 국소의치; 파절저항성; 지대치 간 거리

*교신저자: 신수연

(31116) 충청남도 천안시 동남구 단대로 119 단국대학교 치과대학 치의학과 보철학교실

Tel: 041-550-0256 | Fax: 041-550-1975 | E-mail: syshin@dankook.ac.kr

접수일: 2020년 2월 15일 | 수정일: 2020년 4월 14일 | 채택일: 2020년 5월 11일 